\title{
Antimicrobial Susceptibility and Genetic Characterization of Extended Spectrum Beta-Lactamase (ESBL)-Producing Nosocomial Strains of Escherichia coli Isolated from a Brazilian Teaching Hospital
}

\author{
Rafaele Aragão dos Santos, Vicente de Paulo Teixeira Pinto and \\ Francisco Cesar Barroso Barbosa*
}

\author{
Microbiology Laboratory, FAMED, Federal University of Ceará, Avenida Comandante \\ Maurocélio Rocha Pontes 100, 62.042-280 Sobral, Ceará, Brazil
}

*Corresponding author

\begin{tabular}{l} 
K e y w o r d s \\
$\begin{array}{l}\text { Antimicrobial activity, bla } \\
\text { genes, Escherichia coli, } \\
\text { ESBL, } \alpha \text {-pinene, } \beta \text { - } \\
\text { citronellol, Ipomoea } \\
\text { carnea, Ipomoea asarifolia, } \\
\text { Teaching hospital }\end{array}$ \\
\hline Article Info \\
$\begin{array}{l}\text { Accepted: } \\
\text { 04 July } 2018 \\
\text { Available Online: } \\
\text { 10 August } 2018\end{array}$ \\
\hline
\end{tabular}

Escherichia coli are important pathogens that cause serious infections in hospitalized patients. This study aimed to investigate the occurrence of $\beta$-lactamase genes in twelve ESBL-producing E. coli isolated from patients in the Santa Casa de Misericordia de Sobral-CE, a teaching hospital in Northeastern Brazil, and analyze the antimicrobial susceptibility profile of these microorganisms. Genetic detection of the bla $a_{\mathrm{CTX}-\mathrm{M}}, b l a_{\mathrm{SHV}}$, and $b l a_{\text {TEM }}$ genes was performed by PCR. All isolates were susceptible to ertapenem and meropenem, $11(92 \%)$ were sensitive to amikacin, $9(75 \%)$ to colistin, imipenem and tigecycline. Moreover, $92 \%$ were resistant to ceftriaxone, cefuroxime, cefuroxime/axetil, and $100 \%$ to ampicillin and ciprofloxacin. The $b l a_{\text {СтХ-м gene was detected in } 9(75 \%)}$ isolates, bla $a_{\mathrm{SHV}}$ in $6(50 \%)$, and bla $a_{\mathrm{TEM}}$ in $5(41.6 \%)$. In $3(25 \%)$ of the isolates were detected simultaneously genes encoding all three types of $\beta$-lactamase investigated. Additionally, the antimicrobial activity of $\alpha$-pinenne, $\beta$ - citronellol, Ipomoea carnea and Ipomoea asarifolia extracts against E. coli ATCC 25992 was analyzed, but there was no antimicrobial activity. However, more studies are needed to verify the spread of these organisms in the hospital environment and to evaluate the antimicrobial activity of new compounds and herbal extracts against multidrug resistant pathogens involved in nosocomial infections.

\section{Introduction}

Escherichia coli are gram-negative bacteria that can show resistance to a plethora of clinically important antimicrobial drugs, especially in hospitalized immune compromised patients (O'Connell et al., 2015) and the growing antimicrobial resistance of these microorganisms is an alarming world problem in nosocomial infections which in turns are characterized by clinical manifestation of infections that may affect patients immediately upon hospital admission, during intensive care, or soon after hospital release when they can correlated with hospital procedures (Brasil, 2005).

The Extended Spectrum Beta-Lactamase (ESBL)-producing E. coli outbreak raised the world antimicrobial resistance index (Lago et 
al., 2010), being this phenomenon one of the most significant factors that caused epidemiologic changes in infectious diseases in the last years (Braoios et al., 2009). This increased microbial resistance became a problematic public health issues due to antimicrobial drugs inefficacy in treating pathologies caused by ESBL-producing $E$. coli. In this context, researching novel antimicrobial products is vital.

Amongst many agents, $\alpha$-Pinene, a bicyclic terpene that can be obtained from rosemary essential oil, could be considered a promising component of pharmaceutical formulation to treat infections as it was reported its antimicrobial activity against Streptococcus pyogenes (Sfeir et al., 2013), but a reduced activity against Campylobacter jejuni (Kovac et al., 2015). $\beta$-citronellol is an acyclic monoterpenoid alcohol present in many essential oils such as citronella oil that repels insects. Evidence suggests that citronellol might possess antifungal, antimicrobial (Boukhris et al., 2012), and insecticide functions (Abbas et al., 2012). Efficacy against gram-negative ESBL-producing bacteria, however, has not been proven.

Ipomoea carnea e Ipomoea asarifolia are plant species that belong to the Convolvulaceae family and their extracts can inhibit carbohydrate-metabolizing enzymes (Schwarz et al., 2003). Further, their extracts exhibited antifungal (Lima et al., 2005) and antimicrobial activities versus Staphylococcus aureus, S. epidermidis, Pseudomonas aeruginosa and Escherichia coli strains (Oliveira et al., 2007). Thus, investigating new antimicrobial products is essential to discover novel therapeutics to combat multidrug resistant bacteria.

Genetic characterization and antimicrobial susceptibility of nosocomial ESBL-producing strains along with antimicrobial activity investigation of natural products can contribute to implementing protocols that minimize infection risks, improving the quality of the assistance to hospitalized patients. Hence, this study aims to investigate the occurrence of ESBL-producing $E$. coli isolated from nosocomial diagnosed patients in the teaching hospital Santa Casa de Misericordia de Sobral, Ceará, Brazil; to analyze the antimicrobial resistance profile of the isolated ESBL-producing E. coli versus traditional antimicrobial drugs as well as the antimicrobial activity of $\alpha$-pinene, $\beta$ citronellol, and the Ipomoea carnea e Ipomoea asarifolia extracts against the E. coli strain ATCC 25992.

\section{Materials and Methods}

\section{Bacterial Isolates}

Seventeen E. coli isolates obtained from blood, bodily secretions, urine, and tracheal aspirate samples of patients with diagnosis of nosocomial infection who were hospitalized either in the wards or in the adult or pediatric Intensive Care Unit of Santa Casa de Misericordia de Sobral, between March and August 2014, were analyzed. Twelve out of the seventeen isolates were ESBL-producing strains.

\section{Bacterial Identification}

Sample identification was carried out using the automated Vitek 2 methodology (Biomérieux) in the Division of Microbiology of the Clinical Analysis Service of the mentioned hospital.

After, the isolates identity was confirmed via biochemical tests through biochemical proofs (Enterobacteriacea Kit, Newprov, Pinhais, PR, Brazil) performed in the Laboratory of Microbiology and Parasitology at the Federal University of Ceará, Campus Sobral. 
ESBL Phenotypic Detection and Antimicrobial Susceptibility Test

The Vitek 2 system carried out ESBL phenotypic identification and antimicrobial susceptibility tests (Biomérieux). This automated system utilizes antibioticcontaining cards (AST N105 card) as suggested by the Clinical and Laboratory Standards Institute - CLSI (CLSI, 2017). E. coli strains underwent antimicrobial challenge against: amikacin (AMI), ampicillin (AMP), ampicillin/sulbactam (ASB), cefepime (CPM), cefoxitin (CFO), ceftazidime (CAZ), ceftriaxone (CRO), cefuroxime (CRX), cefuroxime axetil (CRX), ciprofloxacin (CIP), colistin (COL), ertapenem (ERT), gentamicin (GEN), imipenem (IPM), meropenem (MER), piperaciclin/tazobactam (PPT), and tigecycline (TIG). E. coli ATCC 25922 was used as standard strain.

\section{Genomic DNA extraction}

Phenotypically diagnosed ESBL-producing isolates underwent genomic DNA extraction and were stored at $-20^{\circ}$ for posterior ESBL genotypic characterization. Strains were firstly reactivated in BHI broth (Himedia ${ }^{\circledR}$, Mumbai, Índia) for 24 hours, at $37^{\circ} \mathrm{C}$. A $1.0 \mathrm{~mL}$-aliquot, containing approximately $10^{9}$ cells $/ \mathrm{mL}$ of bacterial suspension of each species was used for genomic DNA extraction, utilizing Easy $\mathrm{DNA}^{\mathrm{TM}}$ kit (Invitrogen, USA).

The extracted DNA was then evaluated in regards to its stability in agar gel $0.8 \%$, which previously had ethidium bromide added to it. Electrophoresis was performed at $120 \mathrm{~V}$, for 40 minutes. A $10 \mu 1$-genomic DNA sample added of $2 \mu \mathrm{l}$ of bromophenol blue was applied to the agarose gel. The obtained product was subsequently quantified in spectrophotometer (Gene Quant, Amersham, USA) and a 100nmDNA sample was prepared and stored in $-20^{\circ} \mathrm{C}$ for later use.
Detection and identification of $b l a_{\text {CTX-M, }}$ $b a_{\mathrm{SHV}}$ e $\boldsymbol{b l a}_{\mathrm{TEM}}$ genes by polymerase chain reaction (PCR)

The genetic material of phenotypically diagnosed ESBL-producing isolates underwent PCR to detect $b l a_{\mathrm{CTX}-\mathrm{M}}, b l a_{\mathrm{SHV}}$ and bla $_{\text {TEM }}$ genes.

Primers and previously described protocols (Edelstein et al., 2003; Rasheed, et al., 2007; Chang et al., 2001) were references for amplification of the corresponding fragments of the mentioned genes. Sequences of the amplifiable fragments, annealing temperature, and amplicons are described in table 1.

\section{Plant Sources}

Ipomoea carnea e Ipomoea asarifolia leaves were collected in April 2014, on Olho D'Água farm, located in the town of Catunda, Ceará, Brazil.

Taxonomic identification was done by Professor Elnatan Bezerra de Souza (State University of the Acarau Valley) and exsiccates are in the Francisco José de Abreu Herbarium at the State University of the Acarau Valley, Sobral, Ceará, Brazil.

\section{Extracts Obtention}

Dried leaves $(1.5 \mathrm{Kg})$ were grounded and immersed in ethanol $70 \%$ for seven days. An aliquot from the obtained solution was concentrated by a rotavapor at $50^{\circ} \mathrm{C}$, in vacuum, and then lyophilized for 24 hours, resulting in $35.2 \mathrm{~g}$ of ethanolic extract of $I$. carnea (EEIC) and 39.5 of ethanolic extract of I. asarifolia (EEIA), which were firstly dissolved in distilled water and shaken for 48 hours until complete solubilization. The solutions were thereafter transferred to Falcon tubes and stored at $-20^{\circ} \mathrm{C}$ for posterior analysis. 
Antimicrobial Activity Evaluation of $\alpha$ pinene, $\beta$-citronellol, EEIC, and EEIA

The $\alpha$-pinene, $\beta$-citronellol, EEIC, and EEIA antimicrobial activity was assessed against the standard E. coli strain ATCC 25922 using the micro-dilution technique in 96-well plates according to the CLSI orientation (CLSI, 2017). Each well was filled with $100 \mu \mathrm{L}$ of each compound and extracts, serially diluting the substance in the following well in order to obtain a concentration range from 1.000 to $31.25 \mu \mathrm{L} / \mathrm{mL}$. Following this step, $100 \mu \mathrm{L} / \mathrm{mL}$ of bacterial suspension in broth BHI $\left(2 \times 10^{6}\right.$ UFC. $\mathrm{mL}^{-1}$ ), obtaining a final volume of 200 $\mu \mathrm{L} / \mathrm{mL}$. The plates were then incubated under aerobic conditions $\left(37^{\circ} \mathrm{C} / 24 \mathrm{~h}\right)$. The bacterial growth was determined by the media turbidity in ELISA. After this period, bacterial growth was evaluated.

\section{Ethical Considerations}

This study was approved by the local university ethical committee under the registration number 528.783-CEP-UVA in accordance with the National Health Council resolution $466 / 12$ as well as by the research subcommittee of hospital in which this study was carried out. A unique registration number was attributed to each bacterial isolate and the only information about patients were in regards the date of sample collection, type of clinical sample, and type of ward in which patients were hospitalized.

\section{Results and Discussion}

\section{Bacterial Isolates}

Eighteen isolates were obtained from different patients diagnosed with nosocomial infection who were hospitalized in the mentioned university hospital from March to August 2014. One E. coli isolate (4.54\%) showed conflicting results upon biochemical identification (Enterobactereacea Kit, Pinhais, PR, Brazil) and was, therefore, excluded from this study. The remaining strains $(\mathrm{n}=17)$ had their genus and specie confirmed to be $E$. coli. amongst the 17 analyzed E. coli isolates, 12 (70.58\%) were ESBL-producing strains and 5 (29.42\%) were not. $58.30 \%$ of the clinical samples were collected from patients who had admission to the adult or pediatric Intensive Care Units, followed by other hospital wards. The major part of ESBL-producing strains were isolated from the urine $(n=4,33.33 \%)$ and blood $(n=4,33.33 \%)$, being followed by the tracheal aspirate $(\mathrm{n}=3,25 \%)$, and surgical wound secretion $(\mathrm{n}=1,8.33 \%)$ (Table 2).

\section{Antimicrobial Susceptibility Profile}

Table 3 depicts the antimicrobial susceptibility profile of the ESBL-producing E. coli. Data refer to clinical isolates from patients with nosocomial infection diagnosis in the teaching hospital. They showed a 92\%-resistance profile to amicacin, $75 \%$ were resistant to colistin, imipenem, and tigecycline. Three isolates, however, did not undergo antimicrobial susceptibility test against these last three drugs. In addition, all ESBLproducing strains were susceptible to ertapenem and meropenem, 92\% showed resistance profile to ceftriaxone, cefuroxime, and cefuroxime/axetil, while all the strains resisted to ampicillin and ciprofloxacin.

\section{Screening of $b l a_{\mathrm{CTX}-\mathrm{M}}, b l a_{\mathrm{SHV}}$, and $b l a_{\mathrm{TEM}}$ genes}

Nine out of twelve ESBL-producing E. coli strains $(75 \%)$ amplified a 544bp-fragment, corresponding to the $b l a_{\text {CTX-M }}$ gene codifying region. In regards to the bla $a_{\mathrm{SHV}}$ codifying region, it is highlighted that 6 of the ESBLproducing isolates (50\%) amplified the $861 \mathrm{bp}$ fragment related to the expression of this gene, being it the second most prevalent gene in this study. With regard to bla $a_{\mathrm{TEM}}$ gene 
identification, only 5 isolates $(41.66 \%)$ amplified its corresponding fragment, being it, nonetheless, the least expressed gene in this study. In three ESBL-producers (25\%), it was detected the three ESBL-codifying genes, one isolate $(8.33 \%)$ possessed $b l a_{\mathrm{CTX}-\mathrm{M}}$ and $b l a_{\mathrm{SHV}}$ genes. None of them, however, expressed the combination of $b l a_{\mathrm{SHV}}$ and $b l a_{\mathrm{TEM}}$ genes.

\section{$\alpha$-Pinene, $\beta$-Citronellol, EEIC, and EEIA antimicrobial activity evaluation}

Results demonstrated that $\alpha$-pinene, $\beta$ citronellol, EEIC, and EEIA did not show antimicrobial activity against the standard strain E. coli ATCC 25922 at any tested concentration.

The presumptive ESBL detection does not imply additional costs as the antimicrobial drugs needed to perform such detection can be a part of the antibiotics used routinely in the laboratory. The early detection of these microorganisms, however, is fundamental in order to adopt an efficient patient management within hospitals, avoiding, thus, nosocomial and community outbreaks of resistant bacteria as well as it reduces hospital costs as highlighted Sousa Junior (2004).

ESBL-producing $E$. coli prevalence in this study $(70.58 \%)$ can be considered high and similar to the one reported by Zamparette (2014), whose study demonstrated rates of $69.23 \%$ (9/13) of prevalence of ESBLproducing $E$. coli isolates from hospitalized patients in the university hospital Polydoro Ernani de São Thiago at the Federal University of Santa Catarina, Brazil. Moreover, this study corroborates with data from many other studies Barros (2012); DalBó (2012); Parucker (2014); Rosenthal et al., (2010) and Nogueira et al., (2009) in which ICUs presented the highest rates of infections by E. coli. Most part of the ESBL-expressing strains was isolated from the urine and blood of hospitalized patients as emphasized by the scientific literature Anvisa (2004) whose findings too suggest their occurrence at same sites of infections as the ones reported in this study.

More than half of the E. coli isolates were susceptible to tigecycline. Pereira-Maia et al., (2010) highlight that this antibiotic possesses broad spectrum of action, few side-effects, and it is efficient in combating many bacterial strains that are resistant to many other antimicrobial drugs. Conversely, all isolates showed susceptibility to ertapenem and meropenem. Other studies also confirmed that ertapenem is the most suitable carbapenem antibiotic for ESBL-producing strain identification, especially those isolates that show reduced resistance to carbapenem antimicrobial drugs. These antibiotics easily enter the bacterial structure and are stable when having to face the ESBL hydrolytic action upon them. Nevertheless, studies alarm the emergence of mutant ESBL-producing $E$. coli strains that can resist ertapenem and meropenem attack (Villar et al., 2014).

This study reports that over $90 \%$ of resistant strains were resistant to two or more antimicrobial drugs. Koga et al., (2015) reported the prevalence of $79.30 \%$ of ESBLproducing $E$. coli strains being resistant to three or four antibiotics, being all the isolates at least resistant to one tested antimicrobial drug (Table 4).

The high resistance index to ampicillin is characteristic of ESBL-producing strains. Over $90 \%$ of the E. coli endurance to ampicillin treatment is due to TEM 1 production, one of the enzymes derived from TEM. The observed resistance to ciprofloxacin by all isolates in this study is alarming, since this drug belongs to quinolones group that are broad spectrum antibiotics frequently used to treat gastro 
enteric and genitourinary tract infections. Lujan et al., (2012) analyzed E. coli strains from urinary infections and reported that $60.40 \%$ and $28.30 \%$ of the isolates were resistant to ampicillin and ciprofloxacin, respectively. The analysis of our results draws attention to the importance of a correct therapeutic regimen, especially in the case of patients at high risk of infection. Thus, reducing broad spectrum antibiotics prescription, as well as third and fourth generation cephalosporin drugs seem to be essential to controlling infection outbreaks. A fast and accurate identification of resistance to antibiotics is vital for the adaption of a suitable therapy but it does not provide any information about the genetic mechanisms of resistance involved. This fact limits the use of information about which genes are responsible for mechanisms of resistance that could be communicated in epidemiologic reports.

In this context, molecular biology techniques that constitute an important tool for detecting mechanisms involved in antibiotic resistance due to their high sensitivity and specificity to detect genetic mechanisms of antimicrobial resistance. A rapid identification of the underlying resistance pathways is essential to avoid high dissemination of resistance-related genes between species.

It is important to highlight that controlling the bacterial resistance is directed related to the detection of such mechanisms through laboratorial and molecular tests as well as through the implementation of a rational antibiotic prescription in hospitals.

CTX-M (Cefotaximase) is the main produced enzyme by the $E$. coli isolates analyzed in this study and this reinforces previous data about CTX-M as the most prevalent ESBL worldwide. Seki et al., (2013) reported that the majority part of the ESBL-producing isolates (91\%) had CTM-X as the most synthesized type of ESBL and they still reported a high endemic index of it in Enterobacteriaceae.

Table.1 Primers used for ESBL genes detection by PCR

\begin{tabular}{|c|c|c|c|c|}
\hline Primer name & Primer sequence $\left(5^{\prime}-3^{\prime}\right)$ & Temp* $\left.*{ }^{0} \mathrm{C}\right)$ & $\begin{array}{l}\text { Amplicon } \\
\text { (pb) }\end{array}$ & Reference \\
\hline & Amplification of bla CTХ-M & & & \\
\hline CTX-M F & $\begin{array}{c}\text { TTTGCGATGTGCAGTAC } \\
\text { CAGTAA }\end{array}$ & $51^{\circ} \mathrm{C}$ & 544 & $\begin{array}{l}\text { Edelstein } \text { et al., } \\
2003\end{array}$ \\
\hline \multirow[t]{2}{*}{ CTX-M R } & $\begin{array}{l}\text { CGATATCGTTGGTGGTG } \\
\text { CCATA }\end{array}$ & $51^{\circ} \mathrm{C}$ & 544 & $\begin{array}{l}\text { Edelstein } \text { et al., } \\
2003\end{array}$ \\
\hline & Amplification of $b l a$ SHV & & & \\
\hline $\begin{array}{l}\text { SHV F } \\
\text { (primer 3) }\end{array}$ & $\begin{array}{l}\text { GGGTTATTCTTATTT } \\
\text { GTCGC }\end{array}$ & $56^{\circ} \mathrm{C}$ & 861 & $\begin{array}{c}\text { Rasheed et al., } \\
1997\end{array}$ \\
\hline \multirow[t]{2}{*}{$\begin{array}{l}\text { SHV R } \\
\text { (primer 5) }\end{array}$} & $\begin{array}{c}\text { TTAGCGTTGCCAGTG } \\
\text { CTC }\end{array}$ & $56^{\circ} \mathrm{C}$ & 861 & $\begin{array}{c}\text { Rasheed et al., } \\
1997\end{array}$ \\
\hline & Amplification of $b l a$ TEM & & & \\
\hline TEM F & $\begin{array}{c}\text { ATAAAATTCTTGAAGAC } \\
\text { GAAA }\end{array}$ & $55^{\circ} \mathrm{C}$ & 1088 & $\begin{array}{l}\text { Chang et al., } \\
2001\end{array}$ \\
\hline TEM R & $\begin{array}{l}\text { GACAGTTACCAATGCTT } \\
\text { AATCA }\end{array}$ & $55^{\circ} \mathrm{C}$ & 1088 & $\begin{array}{l}\text { Chang et al., } \\
\quad 2001\end{array}$ \\
\hline
\end{tabular}

*Temp: annealing temperature. 
Table.2 ESBL-producing E. coli isolates distribution according to collection site and hospital unit

\begin{tabular}{|c|c|c|c|c|}
\hline PACIENT & ISOLATE $(\boldsymbol{\%})$ & SITE & HOSPITAL UNIT & ESBL \\
\hline $\mathbf{1}$ & Escherichia coli & Urine & Pediatric ward & NEG \\
\hline $\mathbf{2}$ & Escherichia coli & Blood & Pediatric IUC & NEG \\
\hline $\mathbf{3}$ & Escherichia coli & Tracheal aspirate & Adult IUC & POS \\
\hline $\mathbf{4}$ & Escherichia coli & Tracheal aspirate & Adult IUC & POS \\
\hline $\mathbf{5}$ & Escherichia coli & Blood & Pediatric IUC & POS \\
\hline $\mathbf{6}$ & Escherichia coli & Urine & Pediatric IUC & POS \\
\hline $\mathbf{7}$ & Escherichia coli & Tracheal aspirate & Adult IUC & POS \\
\hline $\mathbf{8}$ & Escherichia coli & Blood & Pediatric IUC & POS \\
\hline $\mathbf{9}$ & Escherichia coli & Urine & Pediatric ward & NEG \\
\hline $\mathbf{1 0}$ & Escherichia coli & Urine & Adult ward & POS \\
\hline $\mathbf{1 1}$ & Escherichia coli & Blood & Adult Emergency Ward & NEG \\
\hline $\mathbf{1 2}$ & Escherichia coli & Blood & Pediatric IUC & NEG \\
\hline $\mathbf{1 3}$ & Escherichia coli & Blood & Adult IUC & POS \\
\hline $\mathbf{1 4}$ & Escherichia coli & Surgical wound secretion & Dom Walfrido Adult ward & POS \\
\hline $\mathbf{1 5}$ & Escherichia coli & Urine & São Joaquim Adult ward & POS \\
\hline $\mathbf{1 6}$ & Escherichia coli & Blood & Adult Emergency Ward & POS \\
\hline $\mathbf{1 7}$ & Escherichia coli & Urine & Pediatric IUC & POS \\
\hline
\end{tabular}

Identification Source: technical reports generated by the automated Gram-negative bacilli identification system Vitek® 2; bio Mérieux, France.

Table.3 ESBL-producing E. coli antimicrobial resistance profile

\begin{tabular}{|c|c|c|c|c|c|c|c|c|}
\hline \multicolumn{9}{|c|}{ E. coli } \\
\hline ANTIBIOTICS & $\mathbf{S}$ & S (\%) & I & I $(\%)$ & $\mathbf{R}$ & $\mathbf{R}(\%)$ & $\begin{array}{c}\text { Non- } \\
\text { evaluated }\end{array}$ & $\begin{array}{c}\text { Non-evaluated } \\
(\%)\end{array}$ \\
\hline Amikacin & 11 & $92 \%$ & 0 & $0 \%$ & 1 & $8 \%$ & 0 & $0 \%$ \\
\hline Ampicillin & 0 & $0 \%$ & 0 & $0 \%$ & 12 & $100 \%$ & 0 & $0 \%$ \\
\hline Ampicillin/sulbactam & 1 & $8 \%$ & 1 & $8 \%$ & 7 & $58 \%$ & 3 & $25 \%$ \\
\hline Cefepime & 4 & $33 \%$ & 3 & $25 \%$ & 5 & $42 \%$ & 0 & $0 \%$ \\
\hline Cefoxitin & 7 & $58 \%$ & 0 & $0 \%$ & 2 & $17 \%$ & 3 & $25 \%$ \\
\hline Ceftazidime & 3 & $25 \%$ & 3 & $25 \%$ & 3 & $25 \%$ & 3 & $25 \%$ \\
\hline Ceftriaxone & 1 & $8 \%$ & 0 & $0 \%$ & 11 & $92 \%$ & 0 & $0 \%$ \\
\hline Cefuroxime & 1 & $8 \%$ & 0 & $0 \%$ & 11 & $92 \%$ & 0 & $0 \%$ \\
\hline Cefuroxime/axetil & 0 & $0 \%$ & 1 & $8 \%$ & 11 & $92 \%$ & 0 & $0 \%$ \\
\hline Ciprofloxacin & 0 & $0 \%$ & 0 & $0 \%$ & 12 & $100 \%$ & 0 & $0 \%$ \\
\hline Colistine & 9 & $75 \%$ & 0 & $0 \%$ & 0 & $0 \%$ & 3 & $25 \%$ \\
\hline Ertapenem & 12 & $100 \%$ & 0 & $0 \%$ & 0 & $0 \%$ & 0 & $0 \%$ \\
\hline Gentamicin & 7 & $58 \%$ & 0 & $0 \%$ & 5 & $42 \%$ & 0 & $0 \%$ \\
\hline Imipenem & 9 & $75 \%$ & 0 & $0 \%$ & 0 & $0 \%$ & 3 & $25 \%$ \\
\hline Meropenem & 12 & $100 \%$ & 0 & $0 \%$ & 0 & $0 \%$ & 0 & $0 \%$ \\
\hline Piperaciclin/tazobactam & 6 & $50 \%$ & 1 & $8 \%$ & 5 & $42 \%$ & 0 & $0 \%$ \\
\hline Tigecycline & 9 & $75 \%$ & 0 & $0 \%$ & 0 & $0 \%$ & 3 & $25 \%$ \\
\hline
\end{tabular}


Table.4 ESBL genes distribution in the $12 \mathrm{E}$. coli isolates according to site of collection and hospital unit

\begin{tabular}{|c|c|c|c|c|c|c|}
\hline Isolate & $\begin{array}{c}\text { Site of } \\
\text { Collection }\end{array}$ & ESBL & $\begin{array}{c}\text { bla } \mathrm{CTX}- \\
\mathrm{M}\end{array}$ & bla TEM & bla $\mathrm{SHV}$ & Hospital Unit \\
\hline Escherichia coli & $\begin{array}{l}\text { Tracheal } \\
\text { aspirate }\end{array}$ & + & + & - & - & Adult ICU \\
\hline Escherichia coli & $\begin{array}{l}\text { Tracheal } \\
\text { aspirate }\end{array}$ & + & + & - & - & Adult ICU \\
\hline Escherichia coli & Blood & + & + & - & - & Pediatric ICU \\
\hline Escherichia coli & Urine & + & + & + & + & $\begin{array}{l}\text { São Joaquim adult } \\
\text { ward }\end{array}$ \\
\hline Escherichia coli & $\begin{array}{l}\text { Tracheal } \\
\text { aspirate }\end{array}$ & + & - & - & + & Adult ICU \\
\hline Escherichia coli & Blood & + & + & + & - & Newborn ICU \\
\hline Escherichia coli & Urine & + & - & - & + & $\begin{array}{l}\text { São Joaquim adult } \\
\text { ward }\end{array}$ \\
\hline Escherichia coli & Blood & + & + & - & - & Adult ICU \\
\hline Escherichia coli & Secretion & + & - & + & - & $\begin{array}{l}\text { Dom Walfrido adult } \\
\text { ward }\end{array}$ \\
\hline Escherichia coli & Urine & + & + & + & + & $\begin{array}{l}\text { São Joaquim adult } \\
\text { ward }\end{array}$ \\
\hline Escherichia coli & Blood & + & + & + & + & $\begin{array}{l}\text { Adult Emergency } \\
\text { ward }\end{array}$ \\
\hline Escherichia coli & Urine & + & + & - & + & Pediatric ICU \\
\hline
\end{tabular}

The CTX-M group originated from the horizontal genetic transference and subsequent mutation of the $A m p C$ (Ampicillinase C) gene of Kluyvera ascorbata. The CTM-X epidemiologic scenario comprises of the insurgence of new enzymes, the existence of multiple clones associated with outbreaks, and the introduction of various genetic elements involved in the bla $a_{\text {СТX-M }}$ gene propagation. The CTM-X dissemination occurred in a way that it could not be solely a consequence of a selective process due to the third-generationcephalosporin overuse, but also as a result of molecular events, for instance, the recombination of the $b l a_{\text {СтX-M }}$ genes with other insertion sequences, transposons activity, and genetic transference via many other moveable genetic elements (Bonnet,
2004; Cantón and Coque, 2006). Thus, this justifies the rapid expansion of the CTX-M ESBL family, increasing from $3 \%$ to $10 \%$ of all known $\beta$-lactamases between 2000 and 2012, respectively (Bush, 2013). Its world propagation in the past 10 to 15 years is one of the fastest and alarming phenomena in the antimicrobial resistance research field.

In Brazil, one of the first descriptions of a CTX-M-belonging enzyme was reported from clinical samples of Enterobacteriaceae collected in many hospitals in Rio de Janeiro from 1996 to 1997 (Bonnet et al., 2000). Since then, CTX-M enzymes has constituted a fast-growth-ESBL family largely distributed in a vast geographical area and amongst a wide range of bacteria, especially in members of the Enterobacteriaceae family. 
The $b a_{\mathrm{SHV}}$ gene was found in half of the analyzed isolates. A study showed that $63 \%$ of nosocomial clinical isolates of Enterobacteriaceae amplified the mentioned gene.

Another investigation done by Tolentino et al., (2011) demonstrated similar results in clinical E. coli isolates from hospitalized patients in the university hospital of Santa Maria, Rio Grande do Sul, Brazil, in which it was observed that $67.80 \%$ of all isolates possessed the aforementioned gene.

The $b l a_{\mathrm{TEM}}$ gene was the least prevalent gene in this study. However, it shows a varied expression pattern in different countries. Bora et al., (2014) described that the most common gene was $b l a_{\text {CTX-M }}(88,67 \%)$, followed by bla $_{\mathrm{TEM}}(77,58 \%)$, and then bla $\mathrm{SHV}(13,20 \%)$ in ESBL-producing $E$. coli isolates in India. In Brazil, two studies reported prevalence numbers of bla $a_{\mathrm{TEM}}$ gene of $82.20 \%$ and 70.0\%, respectively (Abreu et al., 2011; Tollentino et al., 2011).

Amongst different Gram-negative species, bla $a_{\mathrm{TEM}}$ is the most antimicrobial resistanceconferring gene that frequently is detected and, albeit its expression results in resistance to penicillin, diverse punctual mutations of it has contributed to the emergence of ESBL type TEM, culminating in simultaneous resistance to penicillin and narrow-spectrum cephalosporin (Weldhagen et al., 2003).

The genetic resistance accumulation in many strains we observed in this study implies in limited therapeutic options available for nosocomial infection treatment caused by $E$. coli in the investigated hospital.

In another Brazilian state, researchers observed the co-expression of the TEM e CTX-M enzymes in $55.0 \%$ of the ESBLproducing E. coli (Abreu et al., 2011).
In this study there was no evidence of antimicrobial activity of $\alpha$-pinene against the E. coli standard strain ATCC 25922. Studies have demonstrated $\alpha$-pinene modulatory activity in the ciprofloxacin, erythromycin, and triclosan resistance of Cambylobacter jejuni, which can be mediated by a multitude of mechanisms that include the microbial efflux pump, membrane integrity damage, and metabolic disturbance (Kovac et al., 2015). $\alpha$ pinene, however, exhibited reduced antimicrobial activity against $C$. jejuni that could be explained due to an effective bacterial adaptation, leading to efficient changes in the protein synthesis and energetic metabolism.

Contrary to these findings, there is evidence of $\alpha$-pinene exerting antimicrobial activity against Gram-positive bacteria such as Streptococcus pyogenes, Candida species, and Criptococcus neoformans (Lima et al., 2005). Furthermore, other studies reported antimicrobial effects of an essential oil obtained by hydro-distillation of Amomum kravanh fruits, which contain $5.71 \%$ of $\alpha$ pinene in their constitution, on Bacillus subtilis e E. coli (Dião et al., 2014).

Also, it was not observed antimicrobial activity of $\beta$-citronellol against $E$. coli ATCC 259222. Magalhães et al., (2008) emphasized in their investigation that this substance was relatively more effective against Grampositive Bacillus cereus and Staphylococcus aureus rather than against E. coli, a Gramnegative specie.

In addition, Gram-negative bacteria are less susceptible to essential oils than Grampositive ones because the Gram-negative bacteria cellular wall is rich of polysaccharides, being this characteristic responsible for inhibiting the antimicrobial agent penetration. Our findings corroborates with results obtained by Andrade et al., 
(2012) whose study demonstrated that, amongst many tested essential oils, the citronella one showed less efficiency in reducing the analyzed parameters. In regards to the effects of ginger oil on the control of pathogenic bacteria found in food, Singh et al., (2008) applying the agar diffusion method, did not observed zones of inhibition in $E$. coli and $S$. aureus cultures, we too found similar results for E. coli.

Andrade et al., (2012) reported that citronellol was less effective in inhibiting bacterial growth. This result could be related to the presence of cinnamic aldehyde, a major constituent present at high concentration (77.72\%), when compared with other plants studied.

According to Burt (2004), the mechanism of action, therefore, would be similar to other aldehydes, which is normally considered the one that damages to lipids and proteins.

Ipomoea carnea has been extensively studied and its constituents, mainly poly-hydroxylated alkaloids, quantitatively and qualitatively identified due to their action as enzymatic inhibitors of the carbohydrate complex metabolism (Schwarz et al., 2003).

This study, nevertheless, did not verify the antimicrobial activity of $I$. carnea and $I$. asarifolia against the E. coli strain ATCC 25922.

Lima (2005) reported antifungal effects of $I$. asarifolia on 16 strains of dermatophytes fungi, isolated from patients' lesions, inhibiting around $76 \%$ of the tested strains, confirming, thus, the existing pharmacological activity of these species.

Amongst many limitations of this study, we can report that there were not available data about the antimicrobial susceptibility of $25 \%$ of the ESBL-producing E. coli species to different antibiotics, including second and third generation cephalosporins and imipenem. Furthermore, it was not tested the antimicrobial susceptibility of the ESBLproducing $E$. coli from nosocomial infections against the natural compounds $\alpha$-pinene, $\beta$ citronellol, EEIC, and EEIA as they did not inhibit the E. coli standard strain ATCC 25922.

All the ESBL-producing strains were susceptible to ertapenem and meropenem, but showed resistance to ampicillin and ciprofloxacin. Therefore, these carbapenems could be considered the first choice amongst the antimicrobial drugs to treat nosocomial infections caused by multidrug resistant bacteria.

In addition, the $b l a_{\text {CTX-M }}$ gene was detected in the majority of the E. coli isolates, suggesting that CTX-M enzyme is the most prevalent one amongst the E. coli nosocomial isolates in the chosen university hospital.

\section{Acknowledgment}

This research was supported in part by Santa Casa de Misericórdia de Sobral (Edital DEPE 03/2014).

\section{References}

Abbas A. M. et al., 2012. Characteristics of oils and nutrient contents of Nigella sativa linn. and Trigonella foenum-graecum seeds. Bull. Chem. Soc. Ethiop. 26(1), p. 55-64.

Abreu, A. G., Marques, S. G., Monteiro-Neto, V. et al., "Nosocomial infection and characterization of extended-spectrum $\beta$ lactamases-producing Enterobacteriaceae in northeast Brazil", Revista da Sociedade Brasileira de Medicina Tropical, v. 44, n.4, p. 441-446, 2011. 
Andrade, M. A., Cardoso, M. G., Batista, L. R. et al., "Óleos essenciais de Cymbopogon nardus, Cinnamomum zeylanicum e Zingiber officinale: composição, atividades antioxidante e antibacteriana", Revista Ciência Agronômica, v. 43, n. 2, p. 399-408, abr-jun, 2012.

Anvisa. 2004. Infecções relacionadas à assistência à saúde: módulo 4: prevenção de infecções em Unidades de Terapia Intensiva. Anvisa. São Paulo.

Barros, L. M., Bento, J. N. C., Caetano J. Á. et al., 2012. Prevalência de microorganismo e sensibilidade antimicrobiana de infecções hospitalares em unidade de terapia intensiva de hospital público no Brasil. Rev Ciênc Farm Básica Apl., v.33, n. 3, p. 429-435.

Bonnet, R., "Growing Group of ExtendedSpectrum Lactamases: the CTX-M Enzymes", Antimicrobial Agents and Chemotherapy, v. 48, n. 1, p.1-14, 2004.

Bonnet, R., Sampaio, J. L. M., Labia, R. et al., "A novel CTX-M $\beta$-lactamase (CTX-M8) in cefotaxime resistant Enterobacteriaceae isolated in Brazil, Antimicrob. Agents Chemother, v. 44, n. 7, p. 1936-1942, 2000.

Bora, A., Hazarika, N. K., Shukla, S. K. et al., "Prevalência de bla тем, bla bla sHv e genes стХ-м em isolados clínicos de Escherichia coli e Klebsiella pneumoniae do Nordeste da Índia. J Pathol indiano Microbiol, v. 57, n. 2, p. 249-54, 2014.

Boukhris et al., 2012. Hypoglycemic and antioxidant effects of leaf essential oil of Pelargonium graveolens L'Hér. in alloxan induced diabetic rats. Lipids in Health and Disease, p. 11:81.

Braoios, A. T. F. Turatti, L., Meredija, C. S., 2009. Infecções do trato urinário em pacientes não hospitalizados: etiologia e padrão de resistência aos antimicrobianos, J Bras Patol Med Lab. v. 45. n. 6. p. 449456.

Brasil, 2005. Pediatria: prevenção e controle de infecção hospitalar/ Ministério da Saúde, Agência Nacional de Vigilância Sanitária - Brasília: Ministério da Saúde. 116 p.
Burt, S. "Essential oils: their antibacterial properties and potential applications in foods-a review", Int J Food Microbiol, v. 94, n.3, p. 223-53, 2004.

Bush, K., "Proliferation and significance of clinically relevant $\beta$-lactamases", Annals of the New York Academy of Sciences, v. 1277, p. 84-90, 2013.

Cantón, R., Coque T., "The CTX-M betalactamase pandemic. Current Opinion in Microbiology, n.9, p. 466-476, 2006.

Chang, F., Siu, L. K., Fung, C., Huang M., Ho, Monto. 2001. Diversity of SHV and TEM $\beta$-Lactamases in Klebsiella pneumoniae: Gene Evolution in Northern Taiwan and Two Novel $\beta$-Lactamases, SHV-25 and SHV-26", Antimicrobial Agents and Chemotherapy, v. 45 , n. 09, p. 24072413.

CLSI. 2017. Performance Standards for Antimicrobial Susceptibility Testing. 27th ed. CLSI supplement M100. Wayne, PA: Clinical and Laboratory Standards Institute; 2017.

Dal-Bó, K., Silva, R. M., Sakae, T. M. 2012. Infecção hospitalar em uma unidade de terapia intensiva neonatal do Sul do Brasil, Rev Bras Ter Intensiva, v.24, n.4, p.381-385.

Dião, W. R., Zhang, L. L., Feng, S. S., Xu, J. G. "Chemical Composition, Antibacterial Activity, and Mechanism of Action of the Essential Oil from Amomum kravanh", Journal of Food Protection, n. 10, p. 1656-1833, 2014.

Edelstein, M., Pimkin, M., Palagin, Edelstein, I. I., Stratchounski, L. 2003. Prevalence and Molecular Epidemiology of CTX-M Extended-Spectrum $\quad \beta$-LactamaseProducing Escherichia coli and Klebsiella pneumoniae in Russian Hospitals. Antimicrobial Agents and Chemotherapy, v. 47, n. 12, p. 3724-3732.

Koga V. L., Rodrigues G. R., Scandorieiro S. et al., "Evaluation of the Antibiotic Resistance and Virulence of Escherichia coli Strains Isolated from Chicken Carcasses in 2007 and 2013 from Paraná, Brazil”, v.12, n. 6, p. 479-485, 2015. 
Kovac J. et al., 2015. Antibiotic Resistance Modulation and Modes of Action of (-)$\alpha$ Pinene in Campylobacter jejuni. Plos One, v. 1, p. 1-14.

Kovac, J., Simunovic, K., Wu, Z. "Antibiotic Resistance Modulation and Modes of Action of (-)- $\alpha$-Pinene in Campylobacter jejuni", Plos One, v. 1, p. 1-14, 2015.

Lago, A. S., Fuentefria, R., Fuentefria, D. B., 2010. Enterobactérias produtoras de ESBL em Passo Fundo, Estado do Rio Grande do Sul, Brasil. Rev Soc Bras Med Trop, v. 43, n. 4, p. 430-4

Lima, I. O., Oliveira, R. A. G., Lima, E. O. et al., "Inhibitory effect of some phytochemicals in the growth of yeasts potentially causing opportunistic infections", Revista Brasileira de Ciências Farmacêuticas, vol. 41, n. 2, abr./jun., 2005.

Luján, D. A., Luján, L. M., Mamani, E. 2012. Resistência a Antibióticos de Cepas Escherichia coli Isoladas de Infecções do Trato Urinário Adquiridas na Comunidade - Cidade de Lima, Peru", UNOPAR Cient Ciênc Biol Saúde, v.14, n.1, p.17-20.

Magalhães, C. G., Barbosa, L. C. A., Maltha, C. R. A. "Composição química e atividade biológica do óleo essencial de três espécies de Leptospermum", Associação Brasileira de Química - CBQ - $48^{\circ}$ Congresso Brasileiro de Química, 2008. Disponível em http://www.abq.org.br/cbq/2008/trabalhos 17/7-329-2737.htm. Acesso em $10 / 07 / 2015$.

Nogueira, P. S. F., Moura, E. R. F. Costa, M. M. F. et al.,. 2009. Perfil da Infecção Hospitalar em um Hospital Universitário, Rev. enferm. UERJ, v. 17, n. 1, p. 96-101. O'Connell, N. D. Keating, J., Kavanagh et al., 2015. Detection and characterization of extended-spectrum beta-lactamaseproducing Enterobacteriaceae in high-risk patients in an Irish tertiary care hospital. Journal of Hospital Infection, v. 30, p. 16 ,
Oliveira, R. A. G., Lima, E. O., Souza, I. A. 2007. Plantas Medicinais usadas na dermatologia: avaliação da atividade biológica de seus extratos, óleos essenciais e suas associações. Rev enferm UFPE on line, out./dez., v. 1, n. 2, p. 279280.

Parucker, L. M. B. B. Epidemiologia das infecções relacionadas à assistência à saúde na grande Florianópolis, com ênfase em Pseudomonas aerugionosa, Staphylococcus aureus e Escherichia coli, Tese (Doutorado em Microbiologia), Universidade Federal de Minas Gerais, Florianópolis, 2014.

Pereira-Maia, E. C., Silva, P. P., Almeida, W. B. 2010. Tetraciclinas e Glicilciclinas: Uma Visão Geral”, Quim. Nova, v. 33, n. 3, p. 700-706.

Rasheed, J. K., Jay, C., Metchock, F., Berkowitz, L., Weigel, Crellin, J., Steward, C. Hill, B., Medeiros, A. A., Tenover, F. C. 1997. Evolution of Extended-Spectrum $\beta$-Lactam Resistance (SHV-8) in a Strain of Escherichia coli during Multiple Episodes of Bacteremia", Antimicrobial Agents and Chemotherapy, v. 41, n. 03, p. 647-653.

Rosenthal, V. D., Maki, M. D. G., Jamulitrat, S. et al.,. 2010. International Nosocomial Infection Control Consortium (INICC) report, data summary for 2003-2008, issued June 2009, American Journal of Infection Control, v. march, p. 95-104.

Schwarz, A. S. L., Gorniak, M.M., Bernardi, M. L., Dagli, Z., Spinosa, H. S. 2003. Effects of Ipomoea carnea aqueous fraction intake by dams during pregnancy on the physical and neurobehavioral development of rat offspring, Neurotoxicology and Teratology, v. 25, n.5, p. 615-626.

Schwarz, A., Gorniak, S. L., Bernardi, M.M., Dagli, M. L. Z., Spinosa, H. S. "Effects of Ipomoea carnea aqueous fraction intake by dams during pregnancy on the physical and neurobehavioral development of rat offspring", Neurotoxicology and Teratology, v. 25, n.5, p. 615-626, 2003. 
Seki, L. M., Pereira, P. S., Conceição, M. S. et al., "Molecular epidemiology of CTX-M producing Enterobacteriaceae isolated from bloodstream infections in Rio de Janeiro, Brazil: emergence of CTX-M15”, Braz J Infect Dis, v.1 7, n. 6, p. 640 646, 2013.

Sfeir J., 2013. In Vitro Antibacterial Activity of Essential Oils against Streptococcus pyogenes. Evidence-Based Complementary and Alternative Medicine, v. 2013, p. 1-9.

Singh, G., Kapoor, I. P., Singh, P. et al., "Chemistry, antioxidant and antimicrobial investigations on essential oil and oleoresins of Zingiber officinale", Food and Chemical Toxicology. v. 46, n. 10, p. 3295-3302, 2008.

Sousa Junior, M. A., Ferreira, E. S., Conceição, G. C. 2004. Betalactamases de Espectro Ampliado (ESBL): um Importante Mecanismo de Resistência Bacteriana e sua Detecção no Laboratório Clínico, News La, ed. 63 p. 152-174.

Tollentino, F. M., Polotto, M., Nogueira, M. L. et al., 2011. High prevalence of bla(CTXM) extended spectrum betalactamase genes in Klebsiella pneumoniae isolates from a tertiary care hospital: first report of bla(SHV-12), bla(SHV-31), bla(SHV-38), and bla(CTX-M-15) in Brazil, Microb Drug Resist, v.17, n.1, p.7-16.

Villar, H. E., Jugo, M. B., Visser M., Hidalgo M., Hidalgo G., Maccallini G. C., "Rápida adquisición de resistencia in vitro al ertapenem en Escherichia coli productora de betalactamasa de espectro extendido", Rev Esp Quimioter, v. 27, n.1, p. 51-55, 2014.

Weldhagen, G. F., L. Poirel, and P. Nordmann, "Ambler class a extended-spectrum betalactamases in Pseudomonas aeruginosa: novel developments and clinical impact", Antimicrob. Agents Chemother. v.47, p. 2385-2392. 2003.

Zamparette, C. P. 2014. Determinação fenotípica e genotípica de beta-lactamases de espetro estendido em Escherichia coli, Klebsiella pneumoniae e Enterobacter spp. de pacientes internados no Hospital Universitário Professor Polydoro Ernani de São Thiago (HU/UFSC). Dissertação (Mestrado em Farmácia), Universidade Federal de Santa Catarina, Florianópolis.

\section{How to cite this article:}

Rafaele Aragão dos Santos, Vicente de Paulo Teixeira Pinto and Francisco Cesar Barroso Barbosa. 2018. Antimicrobial Susceptibility and Genetic Characterization of Extended Spectrum BetaLactamase (ESBL)-Producing Nosocomial Strains of Escherichia coli Isolated from a Brazilian Teaching Hospital. Int.J.Curr.Microbiol.App.Sci. 7(08): 422-434. doi: https://doi.org/10.20546/ijcmas.2018.708.048 